\title{
Studies on the Homalomeneae (Araceae) of Borneo XXV - A remarkable new kerangas-associated Homalomena [Chamaecladon Clade] from Sabah
}

\author{
Sin Yeng Wong ${ }^{1,2,3}$ (D), Joling Jyloerica ${ }^{1,4}$, Peter C. Boyce ${ }^{3}$ \\ ${ }^{1}$ Institute of Biodiversity and Environmental Conservation, Universiti Malaysia Sarawak, 94300, Kota Samarahan, \\ Sarawak, Malaysia \\ ${ }^{2}$ Harvard University Herbaria, Cambridge, MA, USA \\ ${ }^{3}$ Department Biologie I, Systematische Botanik und Mykologie, Ludwig-Maximilians-Universität München, München, \\ Germany \\ ${ }^{4}$ Forest Research Centre, Sabah Forestry Department, P.O. Box 1407, 90715, Sandakan, Sabah, Malaysia
}

Homalomena portae-inferni is described and illustrated as a new species of the Chamaecladon Clade with scintillating-velutinous foliage restricted to lowland kerangas, and compared with the three morphologically most similar species on Borneo, and with the single other Chamaecladon species described from the Tawau Hills National Park.

\section{Keywords:}

Borneo, Araceae, Homalomena, sulphur springs, kerangas, Tawau Hills National Park

\section{Introduction}

Homalomena Chamaecladon clade (Wong et al. 2013) are mostly diminutive plants, often lithophytic, with small to tiny blooms opening fleetingly before the spathe recloses and persists until fruiting. Post-anthesis the blooms resemble buds except the spent flowers and staminodes have deliquesced, in the process eliminating critical characteristics required for recognition. All Chamaecladon clade species have pistillate florets wherein the staminode is at most half as tall as the associated pistil. The majority of species have a more or less parallel-sided narrowly oblong spathe not exceeding two centimetres long, occasionally only half this, and staminate florets comprised of two stamens. Plants are glabrous, or some or all of the plant, including the spathe exterior, may be scintillating-velutinous, or ornamented with minutely scabrid to asperous trichomes, or with a strigose indumentum, or with extraordinary dense scale-like or soft shaggy trichomes.

\footnotetext{
*Correspondence
}

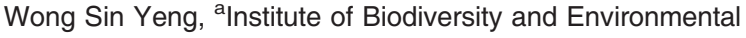

Conservation, Universiti Malaysia Sarawak 94300 Kota

Samarahan, Sarawak, Malaysia

E-mail: sywong@unimas.my

\section{Material and Methods}

While databasing specimens preparatory for the second author's Master's thesis on the Araceae of Sabah it became apparent that herbarium material (J.T. Periera, et al. J.T.P. 572) of a scintillating-velutinous Homalomena from Tawau Hills National Park was not conspecific with the only other species described from Tawau Hills, H. gempal Kartini, P.C.Boyce \& S.Y.Wong (Kartini et al. 2015; Figure 5), and did not match any of the other described species from Sabah. Consequently, it is here published as a taxonomic novelty. Aside from its morphological distinctiveness, it is also remarkable for being the first species restricted to kerangas forest - tropical heath forest in areas with acidic, sandy soils that are extremely nutrient-poor and which undergo periodic water stress (Katagiri et al. 1991).

Geological occurrences in this paper are verified with Tate (2001) and Sanudin et al. (2010).

\section{Taxonomic treatment}

Homalomena portae-inferni S.Y.Wong, J.Joling \& P.C.Boyce, sp. nov. (Figure 1-3, Figure 4A). 